\title{
Vacuum-assisted closure therapy in patients with large postoperative wounds complicated by multiple fistulas
}

\author{
Tomasz Banasiewicz, Maciej Borejsza-Wysocki, Wiktor Meissner, Stanisław Malinger, Jacek Szmeja, Tomasz Kościński, \\ Andrzej Ratajczak, Michał Drews
}

Department of General, Gastroenterological and Endocrine Surgery, Poznan University of Medical Sciences, Poland

Videosurgery and other miniinvasive techniques 2011; 6 (3): 155-163 DOI: 10.5114/wiitm.2011.24694

\begin{abstract}
Vacuum-assisted closure (VAC) therapy is a widely acknowledged method for chronic and traumatic wound healing. The feasibility of VAC therapy used for the treatment of intestinal fistulas is still a subject of debate. Complex postoperative wounds pose significant therapeutic problems, especially when there are several fistula openings in the wound area and other sites, usually at the site of previous drains. This paper describes the treatment of three patients in a critical condition, with complex postoperative wounds complicated by multiple fistulas. Vacuum-assisted closure therapy was based on effective drainage of the biggest fistula opening and ensuring conditions promoting the healing process of other fistulas and the wound. A considerable improvement in general condition and wound healing was noted within 2-4 weeks and both the number of fistulas and the volume of excreted contents decreased. After 5-7 weeks a significant improvement in wound healing was observed in all patients. Once the general condition of all patients was considered satisfactory (2-6 months), they underwent surgery aimed at restoration of the digestive tract continuity.In our opinion, VAC therapy used for the treatment of postoperative wounds with multiple fistulas in the wound area and other sites should aim mainly at the improvement of patients' general condition, limitation of the number of fistulas as well as accelerated wound healing. This may lead to formation of one stoma-type fistula, which can be dressed and cared for by patients until the continuity of the digestive tract has been surgically restored.
\end{abstract}

Key words: vacuum-assisted closure (VAC) therapy, topical negative pressure, enterocutaneous fistula.

\section{Introduction}

Vacuum-assisted closure therapy is a widely acknowledged method of chronic and traumatic wound healing. It was used for the first time in the 1990s [1] for treatment of pressure sores and chronic wounds [2]. In order to achieve negative pressure, a special polyurethane sponge is introduced to the wound bed and secured with an adhesive tape. This dressing, containing a drainage tube, is fitted tightly to a special device which produces constant or intermittent regulated negative pressure [3]. The mecha- nism of VAC therapy is complex. It results in decreased oedema and wound exudates. It also promotes granulation tissue formation by arterial dilatation [4], activates angiogenesis [3] and restores the integrity of capillary basement membranes [5]. Another significant mechanism is a considerable reduction of the number of bacterial cultures [6, 7], which contributes to fewer infectious complications [8]. All these factors account for a greater percentage of recoveries, shorter time of wound healing as well as a reduction in the number of complications [4]. 
Taking into account the complexity of VAC therapy actions as well as the multitude of dressing materials, the range of VAC applications is very wide, from pressure ulcers, leg ulcers, sternal wound infections, mesh grafts, posttraumatic and postoperative wounds, open abdomen treatments [3] to chronic and complicated acute necrotising fasciitis [9].

Complications associated with VAC therapy are rare and usually limited to superficial bleeding occurring after sponge change, pain if the procedure is performed without analgesia or allergic reactions to the drape [4].

Until now, VAC therapy has been contraindicated in the treatment of intestinal fistulas [3] as it may delay the closure of the fistula and cause damage to internal organs [10]. Several reports are available on the efficacy of VAC treatment in the case of certain fistulas [10-15], including in infants [16]. The vast majority of VAC applications concern single fistulas, with one opening in the skin or postoperative/posttraumatic wounds. This paper presents positive outcomes of effective VAC therapy used for the treatment of high output (1500-3000 ml/day), complicated postoperative intestinal fistulas with multiple orifices both in the wound area and other sites.

\section{Case report}

In the present study the V.A.C. ATS Therapy Unit manufactured by $\mathrm{KCl}$ Inc. was used. At the heart of this system is the pump with continuous and intermittent mode of operation, flexible time of active pressure and pause, producing negative pressure of $50-200 \mathrm{mmHg}$ as measured in the wound. Initially, abdominal types of dressings were used, consisting of 1) non-adhesive, perforated film placed on the intestines, 2) polyurethane V.A.C. GranuFoam Standard Dressing $60 \mathrm{~cm} \times 30 \mathrm{~cm} \times 1.5 \mathrm{~cm}$ with open pore structure and hydrophobic construction aiding exudate removal, 3) T.R.A.C Pad allowing for tight connection of sponge and drain, and 4) adhesive V.A.C. Drape. In the authors' Department eight patients with abdominal wounds were treated with VAC therapy. Three patients presented with abdominal wounds with multiple fistulas in and outside the wound. The data concerning VAC therapy in those patients are presented in Table I in the part entitled: Patient characteristics at the onset of treatment.

Initially VAC dressings were changed in a surgical setting. The wound was first cleaned with $0.9 \% \mathrm{NaCl}$ and then the wound and abdominal layers were washed with Octenisept solution. Necrectomy was performed and the wound edges were cleaned, particularly areas which were adjacent to one another and most likely to heal. The surface of intestinal loops filling the wound was covered with non-adhesive drape from the 'Abdominal' set. Initially the sponge was cut to fit the wound size and in the subsequent stages of the treatment it was cut smaller than the wound, fixed with a few 0-2 skin sutures under some tension with the aim of approximating wound edges and thus decreasing the wound size. At the site of the major leakage either a small hole was cut in the sponge or its width was decreased to match the shape of a funnel with the wider part directed at the wound to create the best conditions for intestinal contents to drain out and not to accumulate underneath the sponge.

Exuding considerable amounts of bile and duodenal contents $(1500-3000 \mathrm{ml})$ from the wound and the sites of former drains caused clotting inside the sponge and leaks underneath the drape. That often resulted in decompression of the VAC system.

Thus, the dressings were changed once or twice daily within the first 3 days of treatment. In order to decrease the leakage, single sutures were placed on visible fistula orifices. Fistula openings at the site of previous drains were treated differently: initially with stoma bags and then by application of splints and sealing with gastrostomy drains with distal balloons. Moreover, Stomahesive paste ${ }^{\circledR}$ (ConvaTec, USA) was used to secure the dressing as well as to prevent the leakage of fistula contents below the drape. Depending on the volume and the type of fistula contents the pressure (75-200 $\mathrm{mmHg}$ ) as well as the relation between vacuum and pause periods was adjusted a few times daily. A considerable improvement in general condition and wound healing was observed within 2-4 weeks. Both the number of fistulas and their output decreased. The patients were extubated and their metabolic parameters significantly improved. Decreased levels of CRP and procalcitonin were noted in all cases. The wound was observed to be smaller and the dressings were changed at the bedside every 48-72 $\mathrm{h}$ following the intravenous administration of analgesics. After 5-7 weeks each patient presented with only one narrowed fistula. Once the general condition was considered satisfactory in all patients (2-6 months), they underwent 
Table I. Clinical data, indications and the course of VAC treatment

\begin{tabular}{|c|c|c|c|}
\hline $\begin{array}{l}\text { Patient characteristics } \\
\text { at onset of treatment }\end{array}$ & $\begin{array}{l}\text { Patient 1, F, } 26 \text { years old } \\
\text { 1. Laparoscopic cholecystectomy, } \\
\text { iatrogenic bile duct injury, la- } \\
\text { parotomy, cholecystoduodeno- } \\
\text { stomy. Peritoneal drainage } \\
\text { 2. Relaparotomy due to anasto- } \\
\text { motic insufficiency and dila- } \\
\text { tion of biliary-duodenal fistu- } \\
\text { la. Partial resection of small } \\
\text { intestine. Cholecysto-intesti- } \\
\text { nal anastomosis. Peritoneal } \\
\text { drainage } \\
\text { 3. Relaparotomy. Revision of } \\
\text { cholecysto-intestinal anasto- } \\
\text { mosis and subsequent anas- } \\
\text { tomosis. Dressing of intestin- } \\
\text { al fistula. Peritoneal drainage }\end{array}$ & $\begin{array}{l}\text { Patient 2, M, } 62 \text { years old } \\
\text { 1. Partial sigmoidectomy due to } \\
\text { perforation of inflammatory } \\
\text { tumour of sigmoid colon with } \\
\text { end-to-end anastomosis. Peri- } \\
\text { toneal drainage } \\
\text { 2. Relaparotomy. Eventration. } \\
\text { Anastomotic insufficiency. } \\
\text { Formation of colostomy. Peri- } \\
\text { toneal drainage }\end{array}$ & $\begin{array}{l}\text { Patient 3, M, } 38 \text { years old } \\
\text { 1. Stomach perforation. latro- } \\
\text { genic large bowel injury (pun- } \\
\text { cture lavage). Laparotomy. } \\
\text { Stitching of abdomen and large } \\
\text { bowel. Peritoneal drainage } \\
\text { 2. Relaparotomy. Small bowel } \\
\text { necrosis (approx. } 100 \mathrm{~cm} \text { ), } \\
\text { resection of small bowel - } \\
\text { Hartmann's procedure. Peri- } \\
\text { toneal drainage } \\
\text { 3. Relaparotomy. Small bowel } \\
\text { fistulae. Partial resection of } \\
\text { the distal small intestine. } \\
\text { Another formation of the } \\
\text { stoma. Peritoneal drainage }\end{array}$ \\
\hline $\begin{array}{l}\text { Indications } \\
\text { for VAC therapy }\end{array}$ & $\begin{array}{l}\text { High-output biliary and intestin- } \\
\text { al (duodenal) fistula with two } \\
\text { orifices at the wound site, com- } \\
\text { plete dehiscence of the wound. } \\
\text { Active biliary/intestinal fistula } \\
\text { (1500-2000 ml) out of three } \\
\text { sites of previous drains. Signifi- } \\
\text { cant inflammatory and necrotic } \\
\text { changes of the wound edges. } \\
\text { General condition severe, septic } \\
\text { shock symptoms, multi-organ } \\
\text { insufficiency, mechanical venti- } \\
\text { lation, haemofiltration }\end{array}$ & $\begin{array}{l}\text { Eventration of vast areas of } \\
\text { abdominal layers preventing } \\
\text { their suturing. Conglomerate of } \\
\text { intestinal loops (small intestine) } \\
\text { with at least three active fistu- } \\
\text { lae. Intestinal contents at the } \\
\text { site of previous drain, outside } \\
\text { the wound. Inflamed intestinal } \\
\text { loops, increased adhesions, } \\
\text { impossibility of loop identifica- } \\
\text { tion. Total output of fistulae up } \\
\text { to } 3000 \text { ml. Significant inflam- } \\
\text { matory and necrotic changes of } \\
\text { the wound edges. Inactive sin- } \\
\text { gle-barrel ileostomy. General } \\
\text { condition severe, septic shock } \\
\text { symptoms, multi-organ insuffi- } \\
\text { ciency, mechanical ventilation }\end{array}$ & $\begin{array}{l}\text { Eventration, active intestinal fis- } \\
\text { tula, two orifices at the wound } \\
\text { site, two orifices at the sites of } \\
\text { previous drains, spontaneous } \\
\text { fistula outside the wound, locat- } \\
\text { ed at its inferior pole. Skin and } \\
\text { soft tissue necrosis of stoma } \\
\text { areas. Necrosis of the distal part } \\
\text { of the bowel at the site of the } \\
\text { stoma. Total fistula output rang- } \\
\text { ing from } 2000 \text { to } 2500 \text { ml per } \\
\text { day. Significant inflammatory } \\
\text { changes of the skin at the } \\
\text { wound edges, hypogastrium, } \\
\text { groin, perineum (intestinal con- } \\
\text { tents leakage). General condi- } \\
\text { tion severe. Short bowel syn- } \\
\text { drome. Cachexia. Septic shock. } \\
\text { Systemic mycosis }\end{array}$ \\
\hline 0-7 days & $\begin{array}{l}\text { Dressing changed up to two } \\
\text { times daily. Slight decrease in } \\
\text { fistulae output ( } 1400-1600 \mathrm{ml}) \text {. } \\
\text { Closure of one orifice outside } \\
\text { the wound }\end{array}$ & $\begin{array}{l}\text { Dressing changed every } 24-48 \mathrm{~h} \text {. } \\
\text { Decrease in fistulae output to } \\
\text { approx. } 2000-2500 \mathrm{ml} / \mathrm{day} \text {. The } \\
\text { necessity of using two VAC } \\
\text { drains with Y-convector. De- } \\
\text { crease of CRP and procalcitonin } \\
\text { levels. Extubation on } 6^{\text {th }} \text { day of } \\
\text { VAC therapy }\end{array}$ & $\begin{array}{l}\text { Dressing changed initially every } \\
24-48 \mathrm{~h} \text {. Decrease in fistulae } \\
\text { output }<2000 \mathrm{ml} \text {. General con- } \\
\text { dition improved. Decrease of } \\
\text { CRP level }\end{array}$ \\
\hline 8-14 days & $\begin{array}{l}\text { Dressing changed every } 24-48 \mathrm{~h} \text {. } \\
\text { Gradual contraction of the } \\
\text { wound. Fistula output ranging } \\
\text { from } 500 \text { to } 1500 \mathrm{ml} / \text { day. Clo- } \\
\text { sure of another orifice outside } \\
\text { the wound. Extubation. De- } \\
\text { crease of CRP and procalcitonin } \\
\text { levels. Haemofiltration with- } \\
\text { drawn }\end{array}$ & $\begin{array}{l}\text { Dressing changed every } 48 \mathrm{~h} \text {. } \\
\text { Closure of the fistula orifice out- } \\
\text { side the wound. Contraction of } \\
\text { the wound. Improvement in the } \\
\text { general condition. Decreased fis- } \\
\text { tula output }<2000 \text { per day. Pres- } \\
\text { ence of intestinal contents in } \\
\text { stoma. Initiation of the gradual } \\
\text { closure of the wound with } 0-2 \\
\text { skin sutures, two sutures at the } \\
\text { superior and inferior wound poles } \\
\text { with every dressing changed }\end{array}$ & $\begin{array}{l}\text { Dressing changed every } 48 \mathrm{~h} \text {. } \\
\text { Closure of the fistula orifice out- } \\
\text { side the wound. Fistula output } \\
\text { ranging from } 1500 \text { to } 2000 \mathrm{ml} \text {. } \\
\text { Gradual decrease of necrosis at } \\
\text { the previous stoma site. Decrease } \\
\text { of procalcitonin level. Gradual clo- } \\
\text { sure of the superior pole of the } \\
\text { wound with single sutures. Sig- } \\
\text { nificant inflammatory leakage at } \\
\text { the inferior pole (detachment of } \\
\text { the drape, VAC system impaired) }\end{array}$ \\
\hline
\end{tabular}


Table I. cont.

\begin{tabular}{|c|c|c|c|}
\hline 15-21 days & $\begin{array}{l}\text { Dressing changed every } 48-72 \mathrm{~h} \text {. } \\
\text { Further contraction of the } \\
\text { wound. Closure of fistula ori- } \\
\text { fices outside the wound. Fistula } \\
\text { output }<500 \mathrm{ml} / \text { day. Initiation } \\
\text { of partial enteral nutrition. } \\
\text { Motor rehabilitation }\end{array}$ & $\begin{array}{l}\text { Dressing changed every } 48-72 \mathrm{~h} \text {. } \\
\text { Closure of the fistula orifice at } \\
\text { the wound site. Single VAC } \\
\text { drain. Fistula output } 1000-1500 \\
\mathrm{ml} / \text { day. Further closure of the } \\
\text { wound with single sutures at } \\
\text { dressing changes }\end{array}$ & $\begin{array}{l}\text { Dressing changed every } 48-72 \mathrm{~h} \text {. } \\
\text { Closure of the fistula orifice } \\
\text { outside the wound. Fistula out- } \\
\text { put of } 1000-1500 \mathrm{ml} \text {. Lack of } \\
\text { necrotic changes at the previous } \\
\text { stoma site, granulation tissue } \\
\text { formation, traces of stoma out- } \\
\text { put }\end{array}$ \\
\hline $22-28$ days & $\begin{array}{l}\text { Dressing changed every } 72 \mathrm{~h} \text {. } \\
\text { Reduction of the wound size. } \\
\text { Output } 200-400 \mathrm{ml} / \text { day. Partial } \\
\text { enteral nutrition }\end{array}$ & $\begin{array}{l}\text { Termination of VAC therapy. } \\
\text { Further wound dressing with } \\
\text { stoma equipment. Fistula out- } \\
\text { put } 500 \mathrm{ml} / \text { day, stoma semi- } \\
\text { formed output } 500-1000 \mathrm{ml} / \\
\text { day. Partial enteral nutrition }\end{array}$ & $\begin{array}{l}\text { Dressing changed every } 48-72 \mathrm{~h} \text {. } \\
\text { Fistula output } 500-1000 \mathrm{ml} / \mathrm{day} \text {. } \\
\text { Traces of stoma output. Con- } \\
\text { traction of the wound }\end{array}$ \\
\hline 29-35 days & $\begin{array}{l}\text { Termination of VAC therapy. } \\
\text { Dressing of a minor fistula of } \\
\text { the inferior pole of the wound } \\
\text { with stoma equipment. Full } \\
\text { enteral nutrition }\end{array}$ & & $\begin{array}{l}\text { Dressing changed every } 72 \mathrm{~h} \text {. } \\
\text { Output }<500 \mathrm{ml} \text {. Partial enteral } \\
\text { nutrition. Reduction of the } \\
\text { wound size }\end{array}$ \\
\hline $\begin{array}{l}\text { Further surgical } \\
\text { procedures }\end{array}$ & $\begin{array}{l}\text { At } 6 \text { months following the end } \\
\text { of VAC treatment, reconstruc- } \\
\text { tion of the digestive tract conti- } \\
\text { nuity was performed. No com- } \\
\text { plications occurred }\end{array}$ & $\begin{array}{l}\text { At } 5 \text { weeks following the end of } \\
\text { VAC therapy, laparotomy and } \\
\text { reconstruction of the digestive } \\
\text { tract continuity were performed. } \\
\text { No complications occurred }\end{array}$ & $\begin{array}{l}\text { At } 3 \text { weeks following the end of } \\
\text { VAC therapy, laparotomy and } \\
\text { resection of the distal part of the } \\
\text { small intestine (approx. } 40 \mathrm{~cm} \text { ) } \\
\text { and right hemicolectomy with } \\
\text { side to side ileo-transverse } \\
\text { anastomosis were performed. } \\
\text { No complications occurred }\end{array}$ \\
\hline Equipment & $21 \mathrm{VAC}$ abdominal dressing sets & 11 VAC abdominal dressing sets & 19 VAC abdominal dressing sets \\
\hline
\end{tabular}

surgical reconstruction of the digestive tract continuity. No complications were noted postoperatively.

A description of the treatment course as well as information concerning general condition of the patients at the onset of the treatment, VAC therapy course, its results and dressing changes are presented in Table I. All described patients are still being monitored in the authors' Clinic. Their condition is good and they do not need to follow any particular diet or reduce their physical activity. Their general quality of life is good. They have not required any medical interventions since the last surgical treatment and have returned to their prior duties $(6,12,26$ months). The documentation of treatment of two cases is shown in Figures 1 and 2.

\section{Discussion}

The reduction of septic complications after surgery seems to be a very important factor to improve the results of procedures. The fact that laparoscopy may reduce the number of septic complications in abdominal surgery is well known [17].
In cases of septic complications after laparotomy, including intestinal fistulas, immediate and effective surgical treatment is very important. In the presented cases VAC therapy was used for treatment of chronic and traumatic wounds complicated by multiple fistulas resulting from repeated laparotomies. Patients' general condition, high risk of subsequent surgical intervention, inflammatory reaction and increased intestinal adhesions as well as sepsis resulting from peritonitis ruled out any further operative intervention. Further conservative treatment proved to be ineffective and a great amount of fistula exudates led to the increase of the wound size as well as the development of inflammation and necrosis. Introduction of VAC therapy appeared to be the only alternative for those patients, and it was initiated despite the controversies concerning VAC therapy use for intestinal fistulas [18]. It has been suggested that VAC therapy used for complex wounds with directly exposed intestinal loops might increase the risk of new fistula formation [19, 20]. 

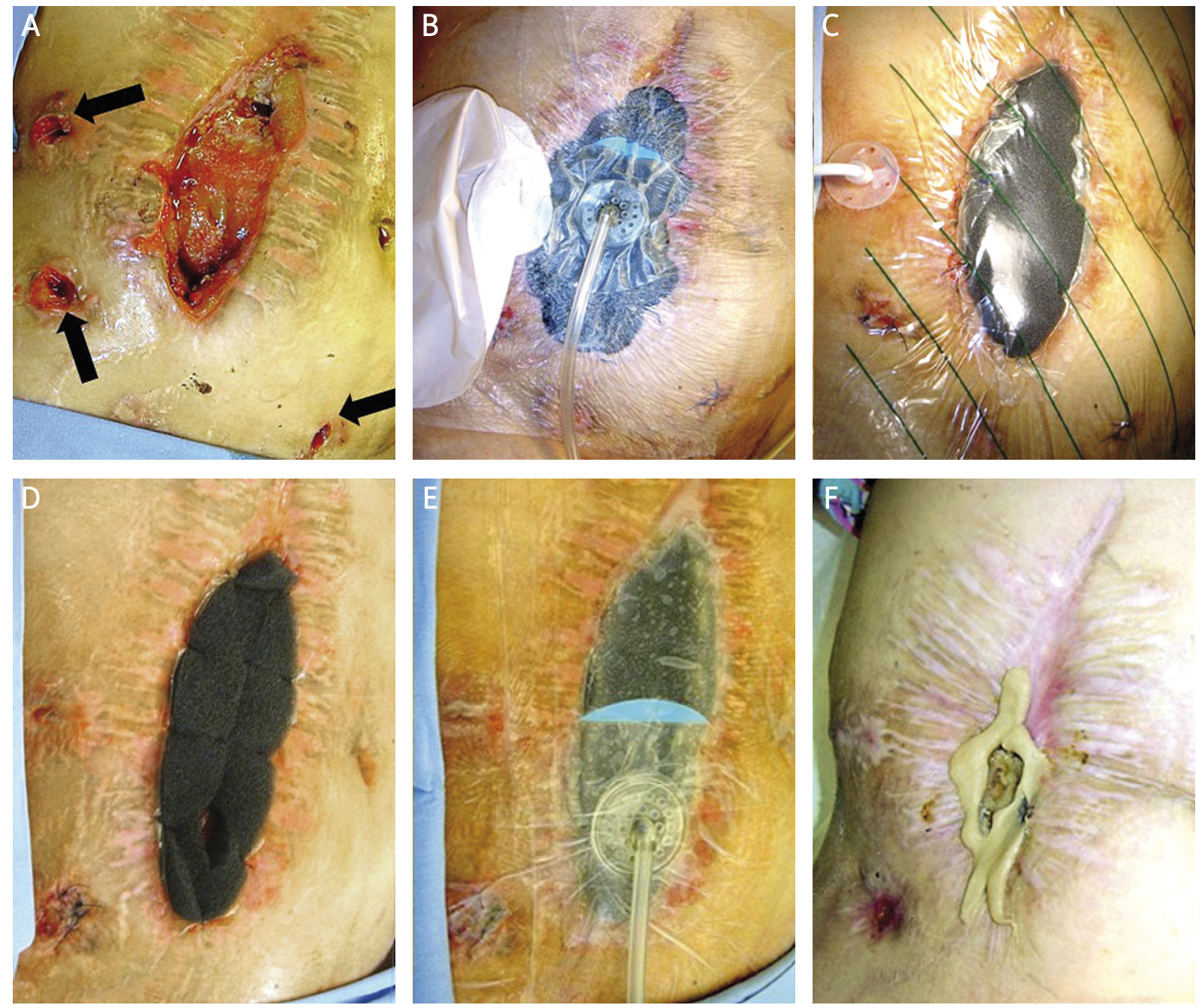

Figure 1. Patient 1. A - wound before VAC treatment, 2 fistulas in wound, 3 enterocutaneous fistulas outside the wound (arrows). B - $6^{\text {th }}$ day of the VAC treatment, changes of the VAC dressings, 2 enterocutaneous fistulas outside the wound closed with sutures, 1 most active fistula secured with stoma bag. $\mathbf{C}-10$ th day of the VAC treatment, reduction of the wound, reduction of the inflammation around the wound. Enterocutaneous fistula secured with gastrostomy tube (balloon insufflated). D - 3 weeks of the VAC treatment, further decrease of the wound. An opening in the lower part of the sponge for better drainage of the fistula. $\mathrm{E}-\mathrm{as}$ in the previous picture, after sponge replacement, constricting effect of the sponge. $\mathrm{F}-6$ weeks of the VAC treatment, wound healed, skin without inflammation, small fistula in the lower part of the wound secured with stoma bag

On the other hand, certain medical papers discuss the positive results of VAC therapy in treatment of intestinal fistulas [10], though the efficacy of VAC therapy is associated mostly with the control of fluid excretion and the improvement of the local conditions of the wounds [21], rather than a complete healing of fistulas, which is very rare [22].

\section{Surgical procedure}

All treated fistulas were heavily exuding, above $500 \mathrm{ml} /$ day according to Berry's classification [23], and they remained so during the first weeks of the treatment. The dimensions of wounds, the number of fistula openings, as well as bile and/or intestinal 

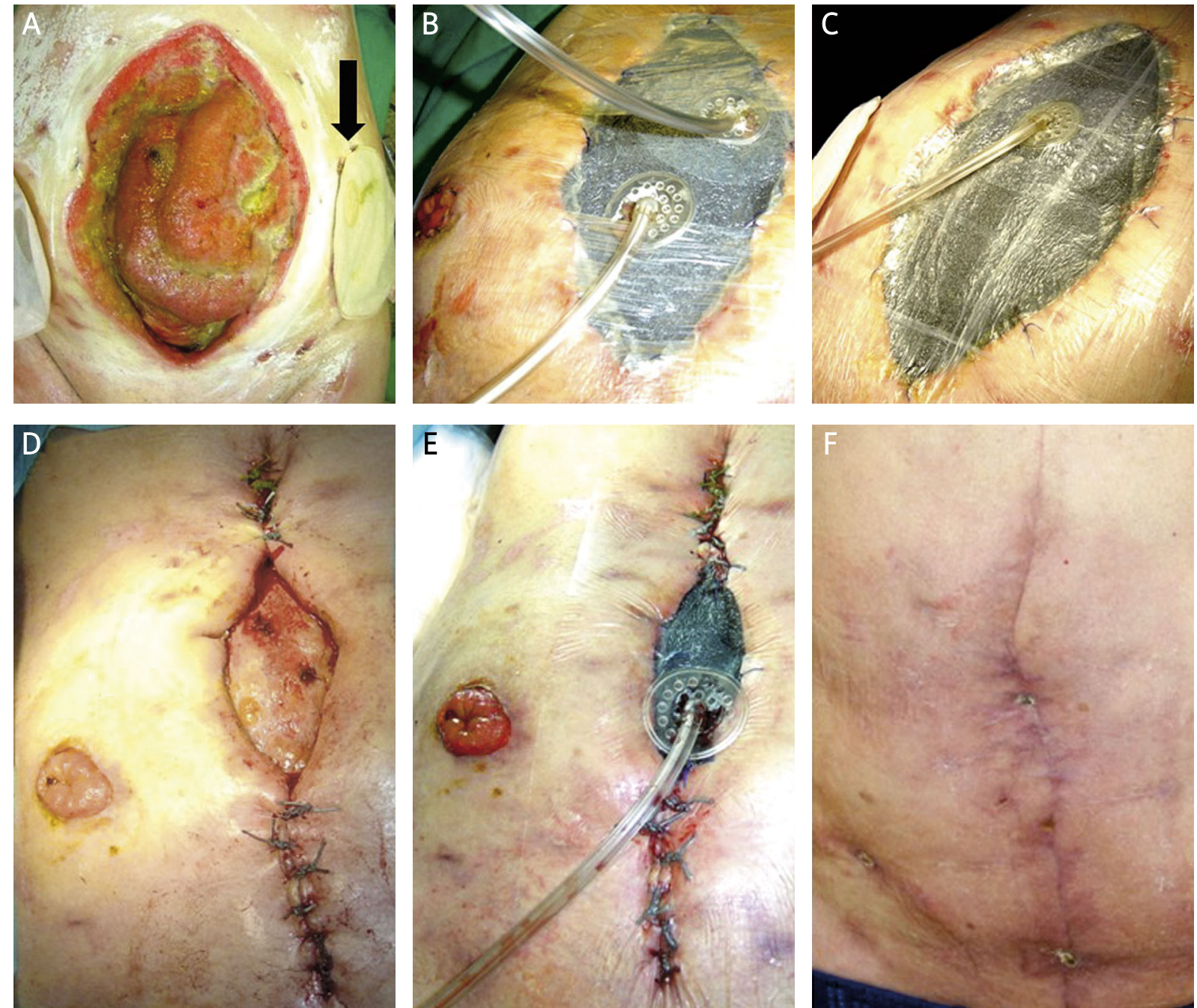

Figure 2. Patient 2. A - wound before the VAC treatment, 3 fistulas in the wound, stoma on the right side, on the left side enterocutaneous fistula outside the wound (black arrow). B - $3^{\text {rd }}$ day of the VAC treatment. Due to high-volume output from fistulas 2 drains with Y-connector. C - 10th day of VAC treatment, decrease of the wound, reduction of the fistula output (only 1 drain above the most active fistula). D - $6^{\text {th }}$ week of the VAC treatment, further decrease of the wound, adaptive sutures on the wound margin. Two fistulas inside the wound. E - as in the previous picture, constricting effect of the sponge after the VAC dressing. $\mathrm{F}-3$ months after therapy and surgical treatment (partial resection of intestine with end-to-end anastomosis)

excretions through sites of former drain tubes, made dressing of these wounds with absorbing drapes and stoma bags, even big ones, impossible. At the onset of VAC therapy our aim was to improve the general condition of patients, accelerate wound healing, and limit the number of fistulas and the amount of their excretion. These goals were to be achieved by successful drainage of fistulas at the site of the most intense excretions, which was thought to lead to a reduction of excretion from other orifices, gradual healing of other fistulas as well as improvement of wound healing. We hoped that a certain type of "steal effect" would occur and that by facilitating the excretion from the widest orifice, the volume and pressure of the contents from other fistulas would decrease. This procedure was thought to lead to the development of a single, active wide fistula of stomalike type, which would require stoma-type dressing 
and possibly surgical reconstruction of digestive tract continuity at a later stage.

In order to achieve the "stoma effect" the orifices of visible fistulas were closed with 3-0 and 4-0 interrupted sutures. Due to significant inflammatory leakage of intestinal wall and fistula orifices, their definite closure was not expected, yet either a temporary closure was obtained or their excretion was limited within a period of 1-2 days, usually before the next change of a dressing. Closure of these orifices positively influenced the local condition of the wound, decreased the inflammatory reaction of the wound edges and the skin and extended the usability of dressing materials.

Another problem significantly impacting VAC therapy and adversely affecting the wound and surrounding skin was the leakage of intestinal and/or bile contents through the sites of former drain tubes. This leakage resulted in the drape's detachment and consequently in decompression of the negative pressure system. In the first days of VAC therapy application this leakage necessitated frequent changes of dressings. The fistula channels were dressed in two manners. One of them was to place stoma bags over the channels at the sites of previous drains. Appropriate fixing of the pouch was particularly difficult due to the short distance between the wound edges and the channels. Both during placement of stoma bags under the drape and placement of the drape over the stoma bags, intestinal contents leaked out and the drape became detached. Despite the fact that the method of using a stoma bag for the treatment of fistulas with VAC therapy has been determined to be helpful in one medical paper [15] we decided to dress channels at the sites of previous drains in a different manner. Here, gastrostomy tubes were placed inside the fistula and the balloon was inflated to make the drain airtight. As a result, more areas for drape sticking were obtained and excretion of contents was limited to a greater extent to the channel. The drain was usually introduced under the drape and sealed with Stomahesive paste. The paste was also used to prevent the gathering of intestinal contents below the drape. Having placed and fixed the sponge with sutures a wide layer of paste was applied to the edges of the wound at the site of wound and drape contact. This way the leakage of intestinal contents was decreased and also the effects of protection and healing were obtained. Limited contact of intestinal contents with wound edges is one of the most signif- icant factors facilitating wound healing [10]. We are of the opinion that using Stomahesive paste with its sealing and healing properties was justified and very effective and it is a standard procedure at our Department.

Healing of traumatic wounds with fistulas and inflammatory reaction is often the cause of widespread adhesions, greatly debilitating future surgical interventions. All treated patients required surgery within 8 weeks to 6 months following VAC therapy. In the opinion of the surgical team, peritoneal adhesions were very limited and all procedures were performed without complications. Our subjective observation concerning faster healing and smaller number of adhesions indirectly confirms the data related to a smaller percentage of abdominal hernia in patients treated with the open abdomen technique using VAC therapy [24]. It needs to be stressed that all treated patients significantly improved their general condition. After 4-7 days of VAC therapy, the levels of CRP and procalcitonin considerably decreased and metabolic and biochemical parameters improved. The general improvement of traumatic wound healing conforms to the observations of other authors [25].

\section{Technical aspects of vacuum-assisted closure therapy}

In all described cases the authors used the standard abdominal set with its crucial element, a nonadhesive drape. It is believed that the reports on additional fistulas developing during VAC therapy for traumatic abdominal wounds $[19,20]$ might result from the lack of or inadequate application of this layer, which may lead to "adherence" of intestinal wall to the sponge and mechanical injury of intestinal serosa during the change of dressing [26]. Therefore, in all cases of dressing change the non-adhesive drape was placed over the surfaces of the intestine and granulation tissue. Ensuring the effective removal of exudates was of crucial importance because fistula exudates, particularly in the initial phase of the treatment, clogged the sponge. This resulted from ineffective VAC functioning and very frequent alarm triggers informing about technical obstacles/drain blockage. Thus, at the site above the most active fistula, the sponge was specifically modified by either having a small opening cut, or decreasing its width in a "funnel" shape manner. Then the sponge was directed with its wider lower base downwards. This allowed for more effective negative pres- 
sure drainage. In order to prevent the sponge and drain clogging as well as to increase the efficacy of drainage, VAC pressure was adjusted within the range $75-200 \mathrm{mmHg}$ depending on the volume of exudate and its pooling below the sponge. The mode of unit operation was also extended when the volume of exudate was high. The majority of authors apply a constant VAC mode, usually $125 \mathrm{mmHg}$ at an intermittent pressure cycle of 5 min suction followed by 2 min off suction [27], although there are also reports describing the application of lower pressures, e.g. $75 \mathrm{mmHg}$ at a constant mode [15]. We are of the opinion that with leakage exceeding $1500 \mathrm{ml} /$ day, as in the presented cases, pressure settings should be adjusted "as needed" to the clinical situation. Due to the fact that some nurses participated in specialist training in pressure adjustments they were able to intervene immediately in the event of pooling of the excessive volume of fistula contents below the sponge. Frequent increase of pressure up to $200 \mathrm{mmHg}$ and the suction of contents excess aided in prevention of leakage below the drape and detachment of the dressing. However, despite the application of all the above-mentioned modifications at the initial stage of VAC treatment (up to 7 days) dressing changes were very frequent, up to 2 times a day. Increased frequency of dressing changes in the case of VAC treatment have also been reported by other authors [15]. Such a necessity should be taken into account during the initial stage of treatment in order to appropriately organize dressing changes and prepare a sufficient number of dressing materials and canisters. Another crucial technical issue is sponge adjustment. It is usually done by tailoring the sponge to fit the shape of the wound. Originally, we also tried this manner of application but later we noticed that the flexible properties of the sponge may prove to be very helpful. During each dressing change we cut the sponge to fit the shape of the wound but also we made sure it was approximately $1 \mathrm{~cm}$ smaller at each side. The sponge was fixed with a few 0-2 skin sutures under certain tension. The great mechanical durability of the sponge and its stretching properties allowed for constant pulling of the wound edges together. We believe that this method enhanced the healing of the wound and reduced the wound size.

One of the greatest technical challenges was to secure the lower part of the dressing. The anatomical shape of the lower part of the abdomen and groin as well as the presence of abdominal folds inhibits the external drape adherence. Moreover, any movement of lower extremities, hygienic procedures related to perineal and anal regions, as well as gravitational leakage of fistula contents towards the lowest part of the wound, made the dressing detached usually in its lower area. The difficulty of appropriate wound dressing in this area is also emphasized by other authors in their papers describing perineal wounds following abdominoperineal resection of the rectum [28]. To prevent this occurrence we applied Stomahesive paste, as described above. Also, an additional suction drain was attached to the lowest part of the wound to allow fistula contents to drain from the wound. We used a system of connectors to be able to use simultaneously two drains, which were connected to a single suction device. Certain modifications have been described related to the increase of the frequency of active evacuation of contents where the drain was incised [29]. However, it is possible only in certain cases as the construction of the drain and the position of channels in its walls allowing for constant pressure monitoring prevent its incision. The application of sets with a Y-connector seems to be most effective, though it certainly increases the costs of the treatment.

\section{Conclusions}

Vacuum-assisted closure therapy positively influences the general condition of patients with chronic and traumatic wounds complicated by multiple fistulas. Application of this method may increase the survival rate and decrease the time of healing. In our opinion, confirmed by observations of other authors, VAC therapy may also lower the overall costs of treatment [30], reducing the number of surgical procedures and the costs of dressing materials and wound care [24]. The fast subsiding inflammatory condition also limits the time of costly antibiotic therapy, particularly in case of the presence of opportunistic bacterial strains.

In the above-described cases a crucial goal was to determine the most preferable drain localization with the aim of facilitating the flow of the widest fistula exudates, at the same time trying to close all other fistula orifices. Frequent change of dressings needs to be taken into consideration. Application of connectors enabling effective negative pressure therapy in several places simultaneously also appears to be very effective. In the case of VAC therapy the likelihood of complete closure of a fistula is small. Thus, the main goal of the treatment is improvement of the 
general health condition, wound healing, formation of the fistula-stoma and finally, the surgical treatment.

From our observations it appears that VAC therapy used for the treatment of vastly dehiscent postoperative wounds complicated by multiple fistulas limits inflammation and the number of adhesions in the abdominal cavity, which is crucial for the subsequent surgical treatments.

\section{References}

1. Argenta LC, Morykwas MJ. Vacuum-assisted closure: a new method for wound control and treatment: clinical experience. Ann Plast Surg 1997; 38: 563-76.

2. Argenta LC, Morykwas M, Rouchard R. The use of negative pressure to promote healing of pressure ulcers and chronic wounds in 75 consecutive patients. Presented at the Joint Meeting of the Wound Healing Society and European Tissue Repair Society, Amsterdam. August 1993.

3. Denzinger S, Luebke L, Burger M, et al. Vacuum-assisted closure therapy in ureteroileal anastomotic leakage after surgical therapy of bladder cancer. World J Surg Oncol 2007; 5: 41.

4. Antony S, Terrazas S. A retrospective study: clinical experience using vacuum-assisted closure in the treatment of wounds. J Natl Med Assoc 2004; 96: 1073-7.

5. Chen SZ, Li J, Li XY, et al. Effects of vacuum-assisted closure on wound microcirculation: an experimental study. Asian I Surg 2005; 28: 211-7.

6. Moues CM, Vos MC, Bemd GJ, et al. Bacterial load in relation to vacuum-assisted closure wound therapy: a prospective randomized trial. Wound Repair Regen 2004; 12: 11-7.

7. Mullner T, Mrkonjic L, Kwasny O, et al. The use of negative pressure to promote the healing of tissue defects: a clinical trial using the vacuum sealing technique. Br J Plast Surg 1997; 50: 194-9.

8. Cresti S, Ouaïssi M, Sielezneff I, et al. Advantage of vacuum assisted closure on healing of wound associated with omentoplasty after abdominoperineal excision: a case report. World J Surg Oncol 2008; 6: 136.

9. Kumar S, O'Donnell ME, Khan K, et al. Successful treatment of perineal necrotising fasciitis and associated pubic bone osteomyelitis with the vacuum assisted closure system. World J Surg Oncol 2008; 6: 67.

10. Cro C, George KJ, Donnelly J, et al. Vacuum assisted closure system in the management of enterocutaneous fistulae. Postgrad Med J 2002; 78: 364-5.

11. Gracias VH, Braslow B, Johnson J, et al. Abdominal compartment syndrome in the open abdomen. Arch Surg 2002; 137: 1298-300.

12. Navsaria PH, Bunting M, Omoshoro-Jones J, et al. Temporary closure of open abdominal wounds by the modified sandwich-vacuum pack technique. Br J Surg 2003; 90: 718-22.

13. Medeiros AC, Aires-Neto T, Marchini JS, et al. Treatment of postoperative enterocutaneous fistulas by high-pressure vacuum with a normal oral diet. Dig Surg 2004; 21: 401-5.
14. Erdmann D, Drye C, Heller L, et al. Abdominal wall defect and enterocutaneous fistula treatment with the Vacuum-Assisted Closure (V.A.C.) system. Plast Reconstr Surg 2001; 108: 2066-8.

15. Goverman J, Yelon JA, Platz J, et al. The "Fistula VAC," a technique for management of enterocutaneous fistulae arising within the open abdomen: report of 5 cases. J Trauma 2006; 60: 428-31.

16. Lopez G, Clifton-Koeppel R, Emil S. Vacuum-assisted closure for complicated neonatal abdominal wounds. J Pediatr Surg 2008; 43: 2202-7.

17. Głowacki J, Stefaniak T, Gruca Z. Surgical site infection in laparoscopic and endoscopic surgery. Videosurgery and other miniinvasive techniques 2008; 3: 10-6.

18. Whelan C, Stewart J, Schwartz BF. Mechanics of wound healing and importance of Vacuum Assisted Closure in urology. J Urol 2005; 173: 1463-70.

19. Rao M, Burke D, Finan PJ, et al. The use of vacuum-assisted closure of abdominal wounds: a word of caution. Colorectal Dis 2007; 9: 266-8.

20. Fischer JE. A cautionary note: the use of vacuum-assisted closure systems in the treatment of gastrointestinal cutaneous fistula may be associated with higher mortality from subsequent fistula development. Am J Surg 2008; 196: 1-2.

21. Ruiz-López M, Carrasco Campos J, Sánchez Pérez B, et al. Negative pressure therapy in wounds with enteric fistulas. Cir Esp 2009; 86: 29-32.

22. Draus JM Jr, Huss SA, Harty NJ, et al. Enterocutaneous fistula: are treatments improving? Surgery 2006; 140: 570-6.

23. Berry SM, Fischer JE. Classification and pathophysiology of enterocutaneous fistulas. Surg Clin North Am 1996; 76: 1009-18.

24. Bertelsen CA, Hillingso JG. The use of topical negative pressure in an open abdomen. Ugeskr Laeger 2007; 169: 1991-6.

25. Dionigi G, Dionigi R, Rovera F, et al. Treatment of high output entero-cutaneous fistulae associated with large abdominal wall defects: single center experience. Int J Surg 2008; 6: 51-6.

26. Wild T, Goetzinger P, Telekey B. VAC and fistula formation. Colorectal Dis 2007; 9: 572-3.

27. Venturi ML, Attinger CE, Mesbahi AN, et al. Mechanisms and clinical applications of the vacuum-assisted closure (VAC) device: a review. Am J Clin Dermatol 2005; 6: 185-94.

28. Schaffzin DM, Douglas JM, Stahl TJ, et al. Vacuum-assisted closure of complex perineal wounds. Dis Colon Rectum 2004; 47: 1745-8.

29. Singh S, Mackey S, Soldin M. VAC it - some techniques on the application of VAC dressings. Ann R Coll Surg Engl 2008; 90 : 161-2.

30. Flack S, Apelqvist J, Keith M, et al. An economic evaluation of VAC therapy compared with wound dressings in the treatment of diabetic foot ulcers. J Wound Care 2008; 17: 71-8. 